Vol. 2 No. 1, 2021

\title{
GREEN ECONOMY: DEVELOPMENT IN THE LIGHT OF NEW POLICY
}

\author{
Mykhailo Sverdan ${ }^{1}$
}

\begin{abstract}
The purpose of the paper is to study the current problems of ecology and environmental protection, which is associated with the current sustainable trends in economic development. The growth of the world economy as a whole and the economic progress of most developed countries with market relations tends to an increasing use of natural resources and at the same time to an increasing depletion and pollution of the environment. The goal is to determine the essence, prerequisites for the emergence and development of the green economy as a modern concept of interaction between society and nature through the economy, as well as reflect the prerequisites for the activation of the green movement on a global scale in order to preserve nature and ensure the natural conditions of human habitation. The topic of the article is due to the need to disclose modern economic dynamics and rates of social progress and their impact on the environment. In this regard, the essence of the green economy, directions and principles of its implementation for the restoration and strengthening of natural potential are considered. Methodology. A correct assessment and analysis of the dynamics and trends in the development of the world economy in terms of increasing economic potential and increasing the production of economic benefits to ensure the welfare of society allows us to assess the level of impact on nature and the environment. Without the results of these assessments and calculations, significant errors appear in the choice of state priorities for socio-economic policy and in making optimal decisions in the field of production. The study is based on an assessment of the interaction between the world economy and the environment in modern conditions. Results. The questions of modern economic trends in nature and environment are studied. The need for the implementation of the green economy in modern conditions has been determined. The necessity to preserve nature and reduce environmental pollution is becoming more and more urgent. Practical implications. The state of the natural environment and the possibilities of preserving and improving the environment are being studied. An adequate assessment of the state of nature and natural resources will allow the world community to pursue a balanced and effective socio-economic and environmental policy for the harmony of society and nature where it lives. Value/originality. It has been determined that nature is the basis of social life, and at the same time, its preservation is the main goal of social progress. The economy is just the means by which nature creates welfare for society. Nature can exist without humanity, but humanity cannot exist without nature. Therefore, the preservation and strengthening of the environment are more than relevant. To this end, a green economy policy is being implemented in the modern world.
\end{abstract}

Key words: economy, nature, civilization, ecology, environment, development.

JEL Classification: O10, Q50

\section{Introduction}

Each era of civilization leaves its mark on the progress of society. Humanity is guided by socio-economic progress in order to improve living conditions and raise living standards. The economy is the basis for creating such conditions; it always strives for growth and development.

From an economic point of view, development consists in a qualitative change in the usual way of life of society. But economic development does not always have a positive vector. Humanity has continuously increased its economic potential, intending to significantly succeed in economic development and surpass all previous results achieved. If in the first stages nature and its fruits were used in their pure form, then later on the use of natural resources began to occur to the detriment of nature itself. So, humanity

Corresponding author:

${ }^{1}$ National University of Life and Environmental Sciences of Ukraine, Ukraine.

E-mail: sverdanof@ukr.net

ORCID: https://orcid.org/0000-0002-1773-3919 
destroys itself in pursuit of economic benefits and enrichment. That is, humanity destroys nature and itself.

The problem of the relationship between economics and nature is one of the most difficult. Does nature produce? Does nature consume? Does nature contribute to value creation and how?

Economics is only a part of human being. Consequently, the solution to the question of the relationship of the economy to nature rests on the solution of a more general issue of the relationship of human to nature. The economy in its most general and simple definition is the product of the process of production and consumption. Therefore, the relation of the economy to nature in its most direct form is the relation of the product to nature. There is the question: nature for people or people for nature?

Human arises from nature; it combines the features created by nature and itself. Nature cannot be separated from humanity because it is the necessary condition for the vital activity of all human beings. It is the foundation for production and consumption.

Society and nature cannot exist in isolation. The economy of primitive society was of an appropriating nature, based on public ownership and an equalized distribution of products. Labour productivity was low, so whatever was produced was consumed. With the advent of the economy, market relations and industrial production, the impact of human on nature began to increase. Until a few hundred years ago, no one cared about the environment. The uncontrolled use of natural resources was common.

At the same time, industrial waste was returned back to nature, ruthlessly causing irreparable harm to it. The destruction of flora and fauna has become widespread and customary. In pursuit of economic benefits, many entrepreneurs overcame all the obstacles, causing more and more harm to nature.

With the development of scientific and technological progress, the impact of society on nature is increasing more and more. The last century is especially indicative in this regard. It was at this time that mass production appeared; human learned to use atomic energy and began to conquer space. Consequently, more powerful sources of pollution of nature appeared, and each of us, without knowing it, participates in this process.
Nature does not accept such human actions. Nature responds with droughts, floods, earthquakes, which humanity has not been able to cope with yet. The influence of human on the surrounding world has acquired such proportions that the issue of nature conservation has become one of the most urgent. In modern society, we can talk about a real ecological crisis. There was a disharmony in the relationship between human and nature. The 20th century was not only the time of the apogee of human impact on nature. Humanity began to think about how to prevent the harmful consequences of its own development.

The protection of nature is the deal of all mankind as a whole and each person individually. Destroying nature, humanity will perish. Nature can exist without humanity, but humanity cannot exist without nature.

\section{Current trends of economic development}

The development of the economic system has a specific character, since it develops under the influence of the characteristics of the evolution of the economic structure. These features are influenced by historical, political, social and cultural factors.

In most modern countries with developed market relations experiencing economic growth, the following trends are observed:

- increase in the value and quality of human resources;

- large amounts of investment;

- improving production efficiency;

- stability and progressiveness of the economy;

- development of the innovation system;

- stable growth of macroeconomic indicators over a long period;

- general improvement in the quality and standard of living of the population.

In most descriptions of the modern historical period, the acceleration of all social, political and economic changes, an increase in the frequency of serious events and shifts are noted as its most important features. At the present stage of the evolution of society, it is imperative to increase the rate of economic growth. This is due to the growing population of the planet and the growth of consumer demands in society in qualitative and quantitative terms.

Currently, the main goal of economic development in most countries of the world and their regions is to improve the quality of life and 
health of the population. Therefore, the process of socio-economic development includes three most important components:

- increasing the level of income, improving the health of the population and raising the level of its education;

- creating appropriate living conditions for people as a result of the formation of favourable infrastructure and institutional system;

- increasing the degree of economic freedom of people.

Some of these goals are identical, but under certain conditions they can differ significantly. Thus, limited funds can be directed either to the development of health care, or to environmental protection (Barry, 1999). A conflict arises between development goals. At the same time, it is clear that the cleaner the environment is, the healthier the population will be and the ultimate goal of human health will be achieved (Abramovay, 2016).

The economic development of many countries is accompanied by a change in the structure of social production, in particular, an industrial society is gradually being replaced by a postindustrial one. An increasing proportion of the employed work in the non-real sector, and a smaller part - directly in industry and agriculture. The standard basic industries cease to be so and will never be base again. Consumption is individualized, the circulation of production is falling, the so-called demassification of production takes place.

Intangible production is becoming a paradigm of economic development, which forces us to reevaluate the degree of wealth of countries and regions. Traditionally, countries are assessed in terms of the endowment of natural resources forests, minerals, soils, climatic conditions, and geographic location.

Over the past few years, economic growth has increased in more than half of the world's countries. The growth rates of the economies of developed countries in these two years have been stable at more than 2 percent. In many countries, these rates were close to their maximum potential values, while the unemployment rate in several developed countries fell to record lows. Global growth remained stable at more than 3 percent in 2018, as slower growth in a number of large economies was offset by acceleration in the United States thanks to fiscal measures.
In 2018, the growth of industrial production and trade in goods around the world is gradually slowing down, especially in the heavily trade-dependent sectors of capital goods and intermediate products. In a number of developed countries, there is already a fairly high level of capacity utilization, which may affect growth in the short term.

Overall macroeconomic performance masks instability and reversal in many developing countries and uneven economic progress around the world. While economic prospects around the world have improved over the past two years, per capita income has been declining in a number of large developing countries.

Even in countries where per capita growth is high, it is often driven by the performance of major industrial areas, leaving peripheral and rural areas behind. Although unemployment rates are at record lows in several developed countries; disposable incomes for many people, in particular, those with low incomes, have increased little or experienced no increase over the past decade. More than half of the world's population lacks access to social protection, which is why a large number of people continue to engage in subsistence farming.

These imbalances make it difficult to meet the challenges of ending poverty and creating decent jobs for all. Low income growth threatens that many other sustainable development goals will also be missed, as countries face difficulties in eliminating infrastructure bottlenecks, improving public health and the quality of human capital.

Behind the sustainable growth of the global economy, there is a gradual rise in a number of short-term risks, which could seriously damage the economy and significantly worsen longterm development prospects. Countries facing significant challenges, such as large macroeconomic imbalances and high levels of external debt, are particularly vulnerable to such risks. As the scope for political action has diminished significantly around the world, any external shock could have serious and long-term implications for global economic growth and socioeconomic status.

A prolonged period of sluggish trade growth will also affect productivity growth in the medium term and hence economic growth in the long term. Trade fosters productivity gains through economies of scale and access to resources, and the acquisition of knowledge and technology through international contacts. In addition, trade in services promotes inclusiveness, resilience building and economic 
diversification. These trade channels are closely linked to investment decisions, productivity gains, economic growth, and ultimately, sustainable development.

There is a growing awareness that the benefits of increased economic integration are not equitably shared between and within countries. The gains from trade liberalization and financial liberalization are now increasingly seen as reasons for increasing inequality in income and wealth within countries, diminishing opportunities for political action, and, in some cases, undermining national sovereignty. The institutions and agreements that play a key role in the multilateral system are coming under increasing pressure. This pressure is being felt in areas such as international trade, international development of finance and climate change.

Climate risks threaten economic prospects. As more extreme weather events occur in the world, climate risks are increasing. More than half of recent extreme weather events are related to climate change. Climate disasters, affecting developed and developing countries alike, place large populations at risk of displacement and severely damage vital infrastructure. However, the vast majority of disaster-related human deaths occur in low-income and lower-middleincome countries. Climate-related damage to critical transport infrastructure could have greater implications for international trade and the prospects for sustainable economic development.

Changes are needed in how global economic development is powered by energy. Reducing global $\mathrm{CO} 2$ emissions is imperative to prevent significant changes in the way people live and natural ecosystems. Despite some progress made in reducing the intensity of greenhouse gas emissions from production, the pace of transition to sustainable production and consumption is not fast enough, which makes it possible to increase carbon emissions and accelerates climate change. In order to avoid further damage to ecosystems and livelihoods, a fundamental and accelerated change in the way world economic development is powered by energy is urgently needed. Economic decision-making needs to take full account of the climate risks associated with carbon emissions, thereby reducing the demand for carbonintensive fossil fuel services and technologies. For countries that continue to rely heavily on fossil fuel production, economic diversification is vital.
In general, a large-scale implementation of energysaving technologies is urgently needed.

\section{Green economy: present condition and new perspectives}

Preservation of nature, ensuring environmental safety have become urgent requirements of modern civilization. The main task of environmental policy is to meet the growing needs of society in the environment, so that its structure, quality and sustainability of processes, functions do not deteriorate and meet the needs of people, as well as the rational and efficient use of natural resources (Cook, 2012).

The issue of environmental order is related to the human right to live and work in a proper environment. Firstly, human rights, and later, the quality of the natural environment were recognized as fundamental values of society, because human could not be separated (isolated) from nature. The concept of the human right to a healthy environment was gradually formulated, which defined the range of its environmental rights. In recent years, the international public consciousness has finally reaffirmed the need to recognize the priority of human rights to a healthy and harmonious environment, formulating the foundations of global environmental policy.

Human rights related to the quality of the environment and its environmental characteristics are enshrined in international treaties and conventions. This is stated in the Universal Declaration of Human Rights, adopted by the UN General Assembly in 1948. In 1966, the International Covenant on Economic, Social and Cultural Rights was adopted. However, environmental rights were not directly stipulated in these and other documents. Only in 1972, the human right to "freedom, equality and adequate conditions of life, in an environment of a quality that permits a life of dignity and well-being" was first recognized at the international level. This was defined in the Declaration of the UN Conference on the Human Environment (Stockholm Declaration).

Green economy is a direction in economic science emerged at the end of the 20th century, within which it is believed that the economy is a dependent component of the natural environment to exist and be a part of it.

Green economy theory is based on three axioms (Goodin, 1992): 
- it is impossible to infinitely expand the sphere of influence in a limited space;

- it is impossible to demand satisfaction of infinitely growing needs in conditions of limited resources;

- everything on the surface of the Earth is interconnected.

Supporters of a green economy consider the desire for economic growth to be unacceptable in modern realities, since it contradicts the first axiom, that is, the planet's natural resources are at their peak of use and further economic growth can lead to an environmental disaster (Henderson, 2006; Makower, 2009).

The main objects of research in the green economy are the following:

- relationship between economic management and the ecological environment of the planet;

- ways of managing such economic systems that include environmental as well as social factors and that would help minimize environmental harm from economic activities in the long term;

- principles on which the development of new technologies in the field of production and management in general should be based, which will also be aimed at minimizing harm to the environment.

The green economy was supposed to be a tool for correcting the situation. As a result, a change in the attitude of society and the economy to wards the environment was foreseen. Despite this, the depletion of nature and environmental pollution continue, which aggravates the problem of ecology. Environmental problems of our time are: climate change; depletion of minerals; pollution of water, land and air; reduction of the ozone layer; radiation pollution; the disappearance of many species of plants and animals and many others; the spread of dangerous viruses and incurable diseases (Brears, 2018; Hoffman, 2008; Marcus, 2011; Young, 2013).

Humankind has to think more and more often about the path along which it is going. Since the beginning of the industrial revolution in the world, a person has not thought about the harm his or her activities cause to the environment. People just do not know about it. However, ignorance of the laws of the environment does not absolve humanity from the responsibility that it bears towards future generations.

The industrial revolution gave birth to the economic model of development that people use to this day. Naturally, this model is effective, because it has existed for more than a dozen years. However, the costs of using it are becoming more apparent (Milani, 2000).

The causes of the global financial, energy and environmental crises are rooted in decades of intensive and unsustainable extraction and use of natural resources, along with poor governance. As a result, a huge, but mostly hidden, environmental debt to the planet and future generations is growing steadily. Naturally, this is a toxic debt that will be difficult for humankind to pay off, given climate change and volatile patterns of growth and consumption. At the same time, this ecological debt is not fully taken into account either in the financial packages of measures to rescue a particular economy, or in the plans for their greening.

The solution to this problem is a green economy. The term "green economy" was first coined in 1989. Until mid-1990, three documents were proposed for the Green Economy.

The Global Green New Deal has called on governments to devote a significant share of funding to green sectors to achieve three goals: economic recovery; eradication of poverty; reduction of carbon emissions and degradation of ecosystems.

The New Deal calls for a Green Economy to deliver sustainable economic growth, with zero carbon emissions, while addressing social equity in a comprehensive manner. A green economy must be not only efficient but also fair.

For the transition to a green economy, developed countries are already developing in all directions. The green economy has six main pillars: renewable energy; sustainable building and energy saving; sustainable transport; water resources management; waste management; land administration and sustainable cities.

Opportunities for the use of renewable energy sources exist all over the world, while other energy sources are concentrated in a limited number of countries. Renewable energy sources are significantly safer for ecosystems, mitigate the effects of climate change, and are also economically beneficial. Renewable energy systems are quickly becoming more efficient and cheaper. Their share in the total energy consumption is increasing.

Green building, or sustainable building, and energy conservation are also part of a green economy. Responsible and efficient use of resources is critical throughout the building's 
lifecycle: from planning to design, construction, operation, maintenance, refurbishment, and ultimately demolition. This requires close collaboration between the contractor, architects, engineers and the client at all stages of the project. The practice of sustainable construction expands and complements the classic problems of building design: utility, durability, comfort and economic problems.

The direction of sustainable transport includes not only transport, but also infrastructure. Transportation systems have a significant impact on the environment and account for $20 \%$ to $25 \%$ of global energy consumption and carbon dioxide emissions. Most of the emissions come from the direct combustion of fossil fuels. Greenhouse gas emissions caused by transport are increasing at a faster rate than that from other anthropogenic activities. Road transport is also one of the main causes of local air pollution and smog.

Water resources management aims at efficient planning, development, distribution and optimal use of water resources. Water management planning strives to allocate water in an equitable manner to meet all uses and requirements. As with other areas of resource management, this is rarely possible in practice.

Waste management is the activity of handling waste from its creation to its final disposal. This includes, but is not limited to, collection, transportation, treatment and disposal of waste, as well as monitoring and regulation. It also covers the legal and regulatory framework. Waste management is necessary to reduce the adverse effects of waste on human health and the environment. If the traditional economy combines labour, technology and resources to produce enduse goods and waste, then a green economy must return waste back to the production cycle with minimal harm to nature.

Land administration and sustainable cities is a management process for the use and development of both urban and rural land resources. Land resources are used for a variety of purposes, which include organic farming, reforestation and ecotourism. Land administration is closely related to water resource management.

The initiatives of the European Union as the most powerful social and economic alliance in the modern world have continued the global trends of preserving the environment and improving natural conditions.
The European Green Deal is a programme of measures aimed at transforming theEuropean Union into a stable, efficient and competitive economy, identifying the means to transform Europe into the world's first climate-neutral continent by 2050 , stimulating economic development, improving health and well-being, transforming climate and environmental challenges into opportunities in all areas, ensuring a fair and inclusive green transition.

The key areas of the European Green Deal are clean energy, climate action, construction and renovation, sustainable industry, sustainable mobility, pollution reduction, biodiversity, sustainable agricultural policy. The European Green Deal concerns mainly the green concept of modernization of the economy and economic growth to ensure human life in harmony with the planet and its resources.

In 2019, the European Commission adopted the Communication on The European Green Deal, which was supported by the European Parliament in early 2020. The European Green Deal is one of the six priorities of the European Commission's Action Plan and sustainable development goals.

The European Green Deal is a new growth strategy aimed at transforming the European continent into a just and prosperous society with a modern, resource-efficient and competitive economy in which net greenhouse gas emissions are zero in 2050 and where economic growth is not linked to growing using resources.

The reform of the European Union's climate policy is focused on addressing three issues:

- reduction of greenhouse gas emissions as a key objective of the European Union's climate policy; - reduction of methane emissions as one of the areas of achieving the climate goals of the European Union;

- adaptation to climate change, which involves the adoption and implementation of comprehensive and integrated measures.

The European Green Deal will possibly be the tool that will start a more respectful attitude of humankind to nature, because the attitude to the environment is the same as the attitude to oneself. An economy of sustainable harmonious development should not contribute to the depletion of renewable resources and worsen the existing natural living conditions (Kenis, 2017).

The transition to a green economy will require special conditions. These favourable conditions include the conditions in which national economies 
are located, domestic and foreign policies, subsidies and incentives, as well as international market and legal infrastructure, trade and technical assistance to developing countries. Currently, favourable conditions have largely been created and are driving the dominant brown economy, which is overly dependent on fossil fuels, depletes resources and degrades the environment (Jacobs, 1991; Kahle, 2014).

Some countries have achieved high levels of human development, but at the expense of their natural resource base, exploitation of the environment and high greenhouse gas emissions. The challenge for these countries is to reduce their per capita greenhouse gas emissions without compromising their quality of life. Other countries still have relatively low levels of pollution per capita, but they need to provide their citizens with a higher level of material well-being. Their task is to do this without significantly increasing their environmental burden on nature (Räthzel, 2014; Richardson, 2013).

\section{Conclusions}

In modern economic conditions, environmental and social factors are becoming increasingly important because since the beginning of the industrial revolution in the world, humanity has not paid enough attention to them. The industrial revolution has given rise to certain problems, primarily related to the environment. Humanity has already realized what consequences the current development model can have. And in the new millennium, the world will have to change this model in favour of one that takes into account environmental and social factors.

However, the world has not come up with a universal model of economic development that would not upset the balance of economic, social and environmental interests. However, humanity is moving in this direction. Realizing the scale of the serious negative consequences of the functioning of the current economic development model, the world is preparing for the transition to a new model. The new model of economic development is called a green economy. The green economy is being talked about more and more often, which is not at all surprising, because it is the economy of the future. The transition to a green economy is inevitable, and therefore many countries are preparing their strategies for the transition to this very model, and the most developed have already taken practical steps in this direction.

Natural resources can create tremendous opportunities for economic development, provided they are used with good governance.

An important problem for the implementation of the ideas of a green economy is mainly selfish motivations for the actions of economic agents. The desire for enrichment and maximum economic benefits is dominant in society.

\section{References:}

Abramovay, R. (2016). Beyond the green economy. Abingdon; New York: Routledge, XVIII, 154 p.

Barry, J. (1999). Rethinking green politics: nature, virtue, and progress. London; Thousand Oaks: SAGE, VIII, $291 \mathrm{p}$.

Brears, R. C. (2018). The green economy and the water-energy-food nexus. London: Palgrave Macmillan, XIV, 423 p.

Cook, S., Smith, K., \& Utting, P. (2012). Green economy or green society?: contestation and policies for a fair transition. Geneva: United Nations Research Institute for Social Development, V, 28 p.

Goodin, R. E. (1992). Green political theory. Cambridge: Polity Press, X, 240 p.

Henderson, H., Sethi, S., \& Lovins, H. (2006). Ethical markets: growing the green economy. White River Junction: Chelsea Green Pub. Company, XXVIII, 256 p.

Hoffman, J., \& Hoffman, M. (2008). Green: your place in the new energy revolution. New York: Palgrave Macmillan, $254 \mathrm{p}$.

Jacobs, M. (1991). The green economy: environment, sustainable development, and the politics of the future. London: Pluto Press, XXII, 312 p.

Kahle, L.R., \& Gurel-Atay, E. (2014). Communicating sustainability for the green economy. Armonk, New York: M.E. Sharpe, X, 302 p.

Kenis, A., \& Lievens, M. (2017). The limits of the green economy: from reinventing capitalism to repoliticising the present. London: Routledge, XVIII, 170p.

Makower, J., \& Pike, C. (2009). Strategies for the green economy: opportunities and challenges in the new world of business. New York: McGraw-Hill, XVII, $290 \mathrm{p}$. 
Marcus, A. (2011). Cross-sector leadership for the green economy: integrating research and practice on sustainable enterprise. New York: Palgrave Macmillan, XXVI, 326 p.

Milani, B. (2000). Designing the green economy: the postindustrial alternative to corporate globalization. Lanham: Rowman \& Littlefield Publishers, XXIV, 235 p.

Räthzel, N., \& Uzzell, D. (2013). Trade unions in the green economy: working for the environment. New York: Routledge, XVI, $266 \mathrm{p}$.

Richardson, R. B. (2013). Building a green economy: perspectives from ecological economics. East Lansing: Michigan State University Press, X, $316 \mathrm{p}$.

Young, M. D., \& Esau, C. (2013). Investing in water for a green economy: services, infrastructure, policies, and management. Abingdon: Routledge, $\mathrm{XX}, 271 \mathrm{p}$. 